\title{
Oxygen store depletion and the aerobic dive limit in emperor penguins
}

\author{
P. J. Ponganis*, J. U. Meir, C. L. Williams \\ Center for Marine Biotechnology and Biomedicine, Scripps Institution of Oceanography, University of California San Diego, \\ La Jolla, California 92093-0204, USA
}

\begin{abstract}
The aerobic dive limit (ADL), dive duration associated with the onset of post-dive blood lactate elevation, has been widely used in the interpretation of diving physiology and diving behavior. However, its physiological basis is incompletely understood, and in most studies, ADLs are simply calculated with an $\mathrm{O}_{2}$ store/ $\mathrm{O}_{2}$ consumption formula. To better understand the ADL, research has been conducted on emperor penguins diving at an isolated dive hole. This work has revealed that $\mathrm{O}_{2}$ stores are greater than previously estimated, and that the rate of depletion of those $\mathrm{O}_{2}$ stores appears to be regulated primarily through a diving bradycardia and the efficiency of swimming. Blood and respiratory $\mathrm{O}_{2}$ stores are not depleted at the $5.6 \mathrm{~min}$ ADL determined by post-dive blood lactate measurements. It is hypothesized that muscle, isolated from the circulation during a dive, is the primary source of lactate accumulation. To predict this 5.6 min ADL for these shallow dives at the isolated dive hole with the classic $\mathrm{O}_{2}$ store/ $\mathrm{O}_{2}$ consumption formula, an $\mathrm{O}_{2}$ consumption rate of $2 \times$ the predicted metabolic rate of a penguin at rest is required. In contrast, if the formula is used to calculate an ADL that is defined as the time for all consumable $\mathrm{O}_{2}$ stores to be depleted, then a 23.1 min dive, in which final venous partial pressure of oxygen $\left(\mathrm{P}_{\mathrm{O} 2}\right)$ was $6 \mathrm{~mm} \mathrm{Hg}(0.8 \mathrm{kPa})$, represents such a maximum limit and demonstrates that an $\mathrm{O}_{2}$ consumption rate of about $0.5 \times$ the predicted rate of an emperor penguin at rest is required in the formula.
\end{abstract}

KEY WORDS: Aerobic dive limit $\cdot$ ADL $\cdot$ Emperor penguins $\cdot$ Heart rate $\cdot$ Lactate $\cdot$ Oxygen $\cdot$ Temperature Resale or republication not permitted without written consent of the publisher

\section{INTRODUCTION}

The aerobic dive limit (ADL), defined originally by Kooyman as the dive duration associated with the onset of post-dive blood lactate accumulation, established the concept that most dives are aerobic, and that it is the efficiency of aerobic metabolism which allows frequent, repetitive dives (Kooyman et al. 1980, Kooyman et al. 1983). The ADL has since become an essential criterion in the evaluation of the foraging ecology and diving behavior of seabirds and marine mammals (Butler \& Jones 1997). Although difficult to measure, ADLs have been estimated frequently by dividing $\mathrm{O}_{2}$ stores by an assumed diving metabolic rate (Gentry \& Kooyman 1986, Kooyman 1989, Butler \& Jones 1997). These calculated aerobic dive limits $\left(\mathrm{ADL}_{\mathrm{C}}\right)$ have been commonly used in interpretations of avian diving behavior. Notably, the dive durations of many seabirds frequently exceed their $\mathrm{ADL}_{\mathrm{C}} \mathrm{S}$ (Table 1). Although hypothermia and the bradycardia of diving have been postulated to contribute to a diving metabolic rate lower than that assumed in the $\mathrm{ADL}_{\mathrm{C}}$ equation (Butler $2004,2006)$, the actual rate and magnitude of oxygen store depletion during dives are largely unknown.

The difficulty of measuring the ADL, the lack of knowledge on its physiological basis, and the remarkable diving capacities of many avian species have led us to conduct research on the physiological responses and management of $\mathrm{O}_{2}$ stores in diving emperor penguins Aptenodytes forsteri. This species is ideal for such investigations because of its size, dive capacity, and ability to dive and forage at an isolated dive hole in the sea ice. The 22-30 kg body mass during the austral spring allows attachment of physiological and behavioral data loggers (Ponganis 2007). Routine dive durations of 5 to $12 \mathrm{~min}$ and dive depths as deep as $500 \mathrm{~m}$ provide sufficient time for those data loggers to acquire a significant number of data points during a 
Table 1. Percentages of dives that are greater than the calculated aerobic dive limits $\left(\mathrm{ADL}_{\mathrm{C}}\right)$ of some avian divers

\begin{tabular}{|lcl|}
\hline Species & \% Dives $>$ ADL $_{C}$ & Source \\
\hline Thick-billed murre Uria lomvia & 48 & Croll et al. (1992) \\
Blue-eyed shag Phalacrorax atriceps & 36 & Boyd \& Croxall (1996) \\
Chinstrap penguin Pygoscelis antarctica & $4-14$ & Culik et al. (1994) \\
Adelie penguin Pygoscelis adeliae & $14-50$ & Chappell et al. (1993), Culik et al. (1994) \\
Gentoo penguin Pygoscelis papua & $20-35$ & Watanuki et al. (1993), Bevan et al. (1995, 2002), Butler (2006) \\
King penguin Aptenodytes patagonicus & $20-40$ & Kooyman et al. (1992a), Culik et al. (1996) \\
\hline
\end{tabular}

given dive (Kooyman \& Kooyman 1995). Lastly, the close access, frequent diving, and guaranteed return of birds and recorders at the isolated dive hole allow application of physiological recorders which could not be successfully deployed on emperor penguins departing on 2 wk foraging trips from the colony (Kooyman et al. 1992b, Ponganis et al. 2009).

Recent investigations conducted at the isolated dive hole of our Penguin Ranch research site in McMurdo Sound Antarctica will be reviewed in an attempt to better understand the depletion of $\mathrm{O}_{2}$ stores, post-dive lactate accumulation, and the ADL of the emperor penguin. It must be emphasized that the findings of these studies apply to emperor penguins diving at an isolated dive hole. This is the only experimental paradigm in which so many parameters could be measured. Determination of the ADL at sea and documentation of physiological responses during dives at sea await future investigation.

\section{Body $\mathrm{O}_{2}$ stores}

On the basis of body mass composition, hemoglobin (Hb) concentration, myoglobin $(\mathrm{Mb})$ concentration, diving air volumes, and the magnitude of $\mathrm{O}_{2}$ extraction during a dive, it has been estimated that emperor penguins can store about $53 \mathrm{ml} \mathrm{O}_{2} \mathrm{~kg}^{-1}$ body mass (Kooyman \& Ponganis 1998). This was similar to estimates of mass specific $\mathrm{O}_{2}$ stores in several penguins and other avian divers (Table 2). However, the distribution of those stores in the emperor penguin was remarkable in that almost half $(47 \%)$ of the body's $\mathrm{O}_{2}$ was located in muscle with $34 \%$ in blood and $19 \%$ in the respiratory system. This contrasted, for example, with the $45 \%$ respiratory component of the total $\mathrm{O}_{2}$ store in the Adelie penguin Pygoscelis adeliae (Chappell et al. 1993), and the 48 to $61 \%$ estimate in the tufted duck Aythya fuligula (Butler 2001). In the latter, the muscle $\mathrm{O}_{2}$ store was estimated at 3 to $4 \%$ of the total $\mathrm{O}_{2}$ store (total $\mathrm{O}_{2}=42$ to $56 \mathrm{ml}$ $\mathrm{O}_{2} \mathrm{~kg}^{-1}$ ).
The difference in $\mathrm{O}_{2}$ store distribution between the emperor penguin and other birds was due to the very high $\mathrm{Mb}$ concentrations in emperor penguin muscle (6.4 g $100 \mathrm{~g}^{-1}$ muscle), and to a relatively low diving air volume (Ponganis et al. 1997a, Ponganis et al. 1999). It had been assumed that the diving air volume of emperor penguins was similar to the value $\left(69 \mathrm{ml}\right.$ air $\mathrm{kg}^{-1}$ body mass) measured during simulated dives in king penguins Aptenodytes patagonicus. This assumption was based on the fact that, of all the penguin species, the king penguin was closest in body mass and diving behavior to the emperor penguin (Kooyman et al. 1992a). More recently, in free dives of king penguins, it has been found that diving air volume ranges from near $70 \mathrm{ml}$ air $\mathrm{kg}^{-1}$ during shallow dives $(<50 \mathrm{~m})$ to $125 \mathrm{ml} \mathrm{kg}^{-1}$ during deep dives (>100 m) (Sato et al. 2002). However, even with greater air volumes during deep dives, the muscle $\mathrm{O}_{2}$ store remains the largest component of the body $\mathrm{O}_{2}$ store (40\% in king penguins, Sato et al. 2002).

\section{Dive behavior and the ADL at the isolated dive hole}

At the isolated dive hole, although dives as deep as $250 \mathrm{~m}$ have occurred, most dives of emperor penguins are $<100 \mathrm{~m}$ in depth (Kooyman et al. 1992b, Ponganis et al. 2004). In fact, the typical dive is usually $<50 \mathrm{~m}$, during which the penguin makes hunting ascents to the underside of the fast ice to capture the sub-ice fish Pagothenia borchgrevinki (Ponganis et al. 2000). Although maximum depths of these dives are at the

Table 2. Oxygen stores in several avian divers. References for assumptions and calculations are as follows: murres (Croll et al. 1992); shags (Kooyman 1989, Boyd \& Croxall 1996); pygoscelid penguins (Chappell et al. 1993, Culik et al. 1994, Bevan et al. 2002, Butler 2006); king penguins (Kooyman et al. 1992a, Culik et al. 1996, Sato et al. 2002). (-) \% distribution not calculated in the shag

\begin{tabular}{|lcccc|}
\hline Species & $\begin{array}{c}\text { Total } \\
\left(\mathrm{ml} \mathrm{O}_{2} \mathrm{~kg}^{-1}\right)\end{array}$ & $\begin{array}{c}\text { Respiratory } \\
(\%)\end{array}$ & $\begin{array}{c}\text { Blood } \\
(\%)\end{array}$ & $\begin{array}{c}\text { Muscle } \\
(\%)\end{array}$ \\
\hline Thick-billed murre & 45 & 53 & 38 & 9 \\
Blue-eyed shag & 46 & - & - & - \\
Pygoscelid penguins & $55-63$ & $32-45$ & $38-29$ & $30-26$ \\
King penguin & $45-54$ & $23-30$ & 30 & $47-40$ \\
\hline
\end{tabular}


shallow end of the emperor penguin's range, dive durations are usually 5 to $10 \mathrm{~min}$, with a maximum recorded duration of $23.1 \mathrm{~min}$ (Ponganis et al. 2007). Swim speeds are 2 to $3.5 \mathrm{~m} \mathrm{~s}^{-1}$, and mean stroke frequencies range from 0.5 to $0.9 \mathrm{~Hz}$ (Kooyman et al. 1992b, van Dam et al. 2002). Horizontal distance travelled from the dive hole averages 400 to $600 \mathrm{~m}$, with a maximum value near $1.2 \mathrm{~km}$ (Shiomi et al. 2008).

For emperor penguins diving at an isolated dive hole, the ADL (dive duration associated with the onset of post-dive blood lactate elevation) has been determined with post-dive blood lactate measurements to be $5.6 \mathrm{~min}$ (Ponganis et al. 1997b). Assuming a body $\mathrm{O}_{2}$ store of $53 \mathrm{ml} \mathrm{O}_{2} \mathrm{~kg}^{-1}$ for shallow dives, this aerobic limit is underestimated by 35 to $55 \%$ in $\mathrm{ADL}_{\mathrm{C}}$ calculations when either the foraging metabolic rate, the overall field metabolic rate, or the lowest flume-swimming metabolic rate is used as the diving metabolic rate in the denominator of the $\mathrm{ADL}_{\mathrm{C}}$ formula (Nagy et al. 2001). In order to use this formula to predict the onset of post-dive lactate accumulation at $5.6 \mathrm{~min}$, a diving metabolic rate of about $1.7 \times$ the predicted $5.5 \mathrm{ml} \mathrm{O}_{2} \mathrm{~kg}^{-1} \mathrm{~min}^{-1}$ metabolic rate of a $25 \mathrm{~kg}$ penguin at rest (Aschoff \& Pohl 1970) would have to be assumed.

\section{PHYSIOLOGICAL RESPONSES}

\section{Background}

Heart rate (HR), locomotory costs, and body temperature are 3 factors that have been considered to contribute to the regulation of $\mathrm{O}_{2}$ store depletion and the duration of the ADL. The decline in HR that occurs during dives of sea birds and marine mammals results in decreased cardiac output and tissue perfusion (Scholander 1940, Folkow et al. 1967, Zapol et al. 1979, Blix et al. 1983) . Hypoperfusion is associated not only with decreased organ $\mathrm{O}_{2}$ consumption, but also with isolation of muscle from the circulation (Scholander 1940, Valtin 1973, Duran \& Renkin 1974, Grubb 1981, Ponganis et al. 2008). These 2 processes decrease the rate of the depletion of the respiratory/blood $\mathrm{O}_{2}$ stores, and, dependent on the degree of muscle ischemia (reduced muscle blood flow), make the duration of aerobic muscle metabolism dependent on the magnitude of the muscle $\mathrm{O}_{2}$ store $(\mathrm{Mb}$ concentration) and on locomotory work effort. Locomotory costs will be a function of hydrodynamics, buoyancy, stroke effort, and stroke-glide patterns (Williams et al. 2000, Williams 2001, Williams et al. 2004).
Decreases in body temperature during dives can affect the diving metabolic rate in 2 ways (Butler 2004, 2006). The occurrence of regional hypothermia during dives theoretically decreases the metabolic cost of thermoregulation during dives in that the additional heat generation to maintain or restore those regional temperatures is not required until the surface interval (Butler 2004). Declines in core or central organ temperature during dives could also decrease the rate at which $\mathrm{O}_{2}$ stores are depleted by depressing tissue metabolic rate through the $\mathrm{Q}_{10}$ effect (Handrich et al. 1997, Butler 2004).

\section{Findings}

The HR response of emperor penguins diving at the isolated hole (Fig. 1) consists of (1) an abrupt decline upon submersion from the pre-dive tachycardia of 180 to 220 beats $\min ^{-1}$ (bpm), (2) a transient elevated HR of 60-100 bpm during the first 2 to $3 \mathrm{~min}$ of the dive, (3) a subsequent, progressive decline in $\mathrm{HR}$ as the dive extends longer with eventual HRs sometimes less than $10 \mathrm{bpm}$, and (4) an increase in HR during the final ascent with a return to a tachycardia (180 to $220 \mathrm{bpm}$ ) during the initial phase of the surface interval (Kooyman et al. 1992b, Meir et al. 2008). This HR profile of emperor penguins diving at the isolated dive hole is consistent with a significant role for HR in determination of the rate of $\mathrm{O}_{2}$ store depletion during dives. It emphasizes the importance of decreased tissue blood 
flow in (1) lowering organ $\mathrm{O}_{2}$ consumption, and (2) especially in longer dives, isolating muscle metabolism from the circulation (Davis \& Kanatous 1999).

The general pattern of HR response in the emperor penguin at the isolated dive hole is similar to that in other penguin species at sea, but it differs in that HR can decline to levels significantly below that at rest (Green et al. 2003, Froget et al. 2004, Meir et al. 2008). As a consequence, dives longer than the ADL have overall HRs that are less than those at rest, and that are distinctly lower than those of dives shorter than the ADL. This contrasts with HR responses in king and macaroni Eudyptes chrysolophus penguins at sea, in which diving HR does not decline significantly below that at rest regardless of dive duration. In part, this difference in the HR response between emperor penguins and the other species may be related to the previously cited differences in $\mathrm{O}_{2}$ store distribution and myoglobin content among these animals. In addition, this difference in HR may also be related to behavioral and physiological differences between dives at the isolated dive hole and dives of emperor penguins at sea.

The locomotory costs of diving animals are a function of hydrodynamics, buoyancy, stroke effort, and strokeglide patterns (Williams et al. 2000, Williams 2001, Williams et al. 2004). In emperor penguins at the isolated dive hole, stroke frequencies and presumed work effort are highest during the initial descent of the dive (van Dam et al. 2002). It is assumed that this increased effort is due to the relative buoyancy of the animal at the start of a dive. While the birds are traveling at depth, stroke frequency is often less than half that during the initial descent with the result that average stroke frequencies of dives decrease as dive durations increase. Emperor penguins at the isolated dive hole do not exhibit prolonged gliding, a potential energy-saving locomotory pattern observed in king and Adelie penguins at sea (Sato et al. 2002) and in many marine mammals (Williams et al. 2000). This may be due to the necessity of horizontal travel under the fast ice and navigation back to the dive hole.

Despite the lack of prolonged gliding at the isolated dive hole, mass-specific field metabolic rates and foraging metabolic rates of emperor penguins are the lowest among 8 penguin species (Nagy et al. 2001). The efficiency of their swimming is reflected by the fact that the field metabolic rates of emperor penguins foraging at the isolated dive hole are indistinguishable from those of hand-fed, non-diving birds (Nagy et al. 2001). A presumably low locomotory muscle metabolic rate combined with the high $\mathrm{Mb}$ content of emperor penguin muscle should maximize the potential duration of aerobic metabolism in muscle, and contribute to the duration of the ADL.

Temperature studies at the isolated dive hole have revealed that regional hypothermia occurs in diving emperor penguins, but that core temperature is preserved (Ponganis et al. 2001, Ponganis et al. 2003, Ponganis et al. 2004). Temperatures in foot veins, wing veins, and the abdomen behind the brood patch can decline significantly (i.e. to $<30^{\circ} \mathrm{C}$ ) during dives. However, temperatures in the aorta, inferior vena cava, pectoral muscle, and deep axillary and femoral veins are preserved and sometimes increased during dives. Even during a $23.1 \mathrm{~min}$ dive (Fig. 2), vena caval temperature was 36.3 to $36.7^{\circ} \mathrm{C}$, within the same range as that of the penguin at rest (Ponganis et al. 2007). Hypothermia in the peripheral body regions of emperor penguins at the isolated dive hole may thus decrease the metabolic cost of thermoregulation during dives in that heat need not be generated to warm those regions during the dive. However, the lack of central core hypothermia argues that hypothermiainduced reductions in tissue metabolic rate do not play a role in extending the duration of aerobic metabolism in these birds. The cost of thermoregulation in blue-eyed shags Phalacrorax atriceps, Brümmich's guillemots Uria lomvia and several penguin species may also be decreased due to regional hypothermia

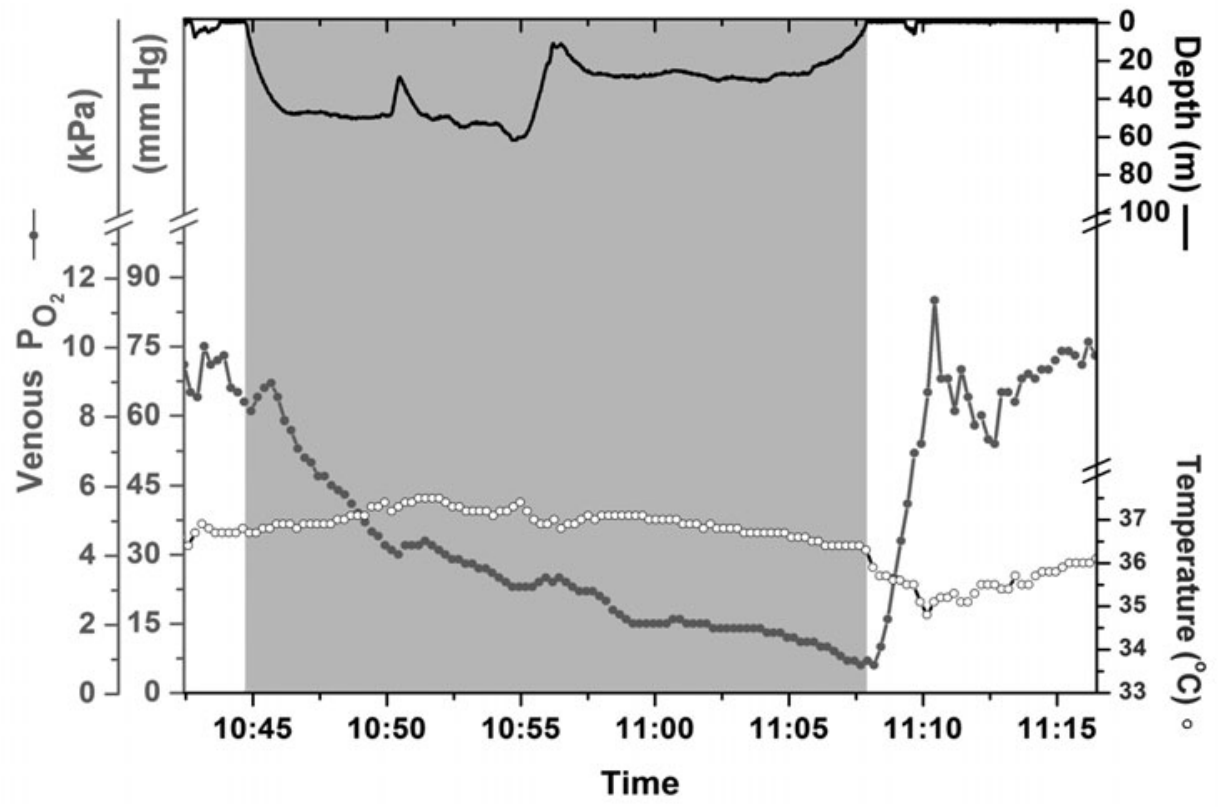

Fig. 2. Aptenodytes forsteri. Depth profile, vena caval $\mathrm{P}_{\mathrm{O} 2}$ and temperature profiles during a 23.1 min dive (data from Ponganis et al. 2007). $\mathrm{P}_{\mathrm{O} 2}$ : partial pressure of oxygen; grey background: dive time 
as dive temperature profiles behind the brood patch are similar in pattern to those in emperor penguins (Bevan et al. 1997, Handrich et al. 1997, Bevan et al. 2002, Green et al. 2003, Niizuma et al. 2007). Core temperature, however, is not reduced in Brummich's guillemots during dives (Niizuma et al. 2007). Whether core temperature reductions and hypothermia-induced metabolic depression in central $\mathrm{O}_{2}$ consuming organs occur during dives still remains to be determined in the other species.

\section{$\mathrm{O}_{2}$ store depletion during dives}

To better understand the physiological basis of the $\mathrm{ADL}$, it is necessary to examine not just the above physiological responses, but also the actual rate and magnitude of the depletion of the body $\mathrm{O}_{2}$ stores during dives. Investigation of air sac, arterial, and venous $\mathrm{P}_{\mathrm{O} 2} \mathrm{~S}$ during dives have now been accomplished in emperor penguins with use of a customized backpack recorder and a commercially available intravascular $\mathrm{O}_{2}$ electrode (Stockard et al. 2005, Ponganis et al. 2007, Meir \& Ponganis 2009, Ponganis et al. 2009).

\section{$\mathrm{O}_{2}$ status at the $\mathrm{ADL}$}

These studies have revealed that, at the ADL of $5.6 \mathrm{~min}$, the respiratory and blood $\mathrm{O}_{2}$ stores are not depleted. For dive durations near 5.6 min, final air sac, arterial and venous $\mathrm{P}_{\mathrm{O} 2} \mathrm{~S}$ were as high as 87 , 75, and $46 \mathrm{~mm} \mathrm{Hg}$, respectively $(11.7,10$, and $6.1 \mathrm{kPa})$. These values correspond, respectively, to an air sac $\mathrm{O}_{2}$ fraction near $12.2 \%$, and blood $\mathrm{P}_{\mathrm{O} 2} \mathrm{~S}$ greater than venous values of emperor penguins at rest. End-of-dive $\mathrm{Hb}$ saturation data, based on the $\mathrm{P}_{\mathrm{O} 2}$ electrode data and the $\mathrm{O}_{2}-\mathrm{Hb}$ dissociation curve of emperor penguin $\mathrm{Hb}$, also demonstrate that arterial and venous blood are not depleted of $\mathrm{O}_{2}$ at the 5.6 min ADL (Meir \& Ponganis 2009).

It was also notable that the final $\mathrm{P}_{\mathrm{O} 2} \mathrm{~S}$ at 5.6 min spanned a large range, as much as $40 \mathrm{~mm} \mathrm{Hg}(5.2 \mathrm{kPa})$ for the arterial and venous data (Ponganis et al. 2009). This supports past suggestions that metabolic rate during a dive is variable and dependent on the nature and circumstances of a given dive. The wide range of $\mathrm{P}_{\mathrm{O} 2} \mathrm{~S}$ at the $\mathrm{ADL}$ also raises the question that perhaps the lowest arterial and venous $\mathrm{P}_{\mathrm{O} 2} \mathrm{~S}$ at $5.6 \mathrm{~min}$ might be associated with the onset of a net increase in anaerobic metabolism and blood lactate accumulation in perfused organs during the dive.
However, blood lactate concentrations, determined from blood samples obtained as far as 10.5 min into a dive, do not increase significantly above levels at rest and do not support that possibility (Ponganis et al. 2009). Furthermore, similarly low blood $\mathrm{P}_{\mathrm{O} 2} \mathrm{~s}$ during sleep apnea of another premier diver, the elephant seal Mirounga angustirostris, are also not associated with blood lactate accumulation (Castellini et al. 1986, Stockard et al. 2007).

These findings document that the blood and respiratory $\mathrm{O}_{2}$ stores are not depleted at the ADL in emperor penguins diving at the isolated dive hole. They also support the concept that increased anaerobic metabolism and net lactate accumulation in perfused organs do not occur even at the low end of the range of blood $\mathrm{P}_{\mathrm{O} 2}$ values measured at the $5.6 \mathrm{~min}$ ADL. This leads to the hypothesis that active, but nonperfused muscle is the most likely source of lactate accumulation at the ADL. Heart rate profiles, the lack of evidence for muscle $\mathrm{O}_{2}$ extraction in venous $\mathrm{P}_{\mathrm{O} 2}$ profiles, increased intradive pectoral muscle temperatures, and a lack of blood lactate elevation until the post-dive period in emperor penguins all suggest that muscle is isolated from circulation during diving, and that lactate washout from muscle only occurs during the tachycardia and increased muscle blood flow of the post-dive period (Ponganis et al. 2003, Meir et al. 2008, Ponganis et al. 2009). The rate and magnitude of depletion of the large muscle $\mathrm{O}_{2}$ store during dives of emperor penguins at the isolated dive hole awaits investigation.

Table 3. Aptenodytes forsteri. Magnitude and distribution of $\mathrm{O}_{2}$ stores. A range of values is provided because of potential differences in the magnitude of the respiratory $\mathrm{O}_{2}$ store. The size of the respiratory $\mathrm{O}_{2}$ store (Resp. $\mathrm{O}_{2}$ ) is dependent on (1) diving air volume (DAV) $69 \mathrm{ml} \mathrm{kg}^{-1}$ for shallow dives and $125 \mathrm{ml} \mathrm{kg}^{-1}$ for deep dives (Ponganis et al. 1999, Sato et al. 2002) and (2) the change in the air sac $\mathrm{O}_{2}$ fraction $\left(\Delta \mathrm{FO}_{2}\right)$ : the previously assumed 15 vs. $19 \%$ from air sac $\mathrm{P}_{\mathrm{O} 2}$ data (Kooyman \& Ponganis 1998, Stockard et al. 2005). The blood $\mathrm{O}_{2}$ store $\left(21.1 \mathrm{ml} \mathrm{O}_{2} \mathrm{~kg}^{-1}\right)$ is based on a hemoglobin [Hb] of $18 \mathrm{~g} \mathrm{dl}^{-1}$, blood volume of $100 \mathrm{ml} \mathrm{kg}^{-1}$, a maximal decline in arterial $\mathrm{Hb}$ saturation from 95 to $10 \%$, a maximal decline in venous $\mathrm{Hb}$ saturation from 90 to $0 \%\left(1.34 \mathrm{ml} \mathrm{O}_{2} \mathrm{~g} \mathrm{Hb}^{-1}\right)$ and a blood volume distribution of 0.33 arterial and 0.67 venous (Kooyman \& Ponganis 1998, Ponganis et al. 1997a, 2007). The muscle $\mathrm{O}_{2}$ store $\left(24.4 \mathrm{ml} \mathrm{O} \mathrm{kg}^{-1}\right)$ is based on complete desaturation of $100 \%$ saturated myoglobin $(\mathrm{Mb})(1.34$ $\mathrm{ml} \mathrm{O}_{2} \mathrm{~g} \mathrm{Mb}^{-1}$ ), a Mb concentration of $6.4 \mathrm{~g} 100 \mathrm{~g} \mathrm{muscle}^{-1}$ in the pectoralis-supracoracoideus muscles, and $2.1 \mathrm{~g} 100 \mathrm{~g} \mathrm{muscle}^{-1}$ in other muscles, a pectoralis-supracoracoideus muscle mass of $25 \%$ body mass, and a mass of $12 \%$ body mass for other muscles (Ponganis et al. 1997a)

\begin{tabular}{|lcccccc|}
\hline $\begin{array}{l}\mathrm{DAV} \\
\left(\mathrm{ml} \mathrm{kg}^{-1}\right)\end{array}$ & $\begin{array}{c}\mathrm{FO}_{2} \\
(\%)\end{array}$ & $\begin{array}{l}\text { Resp. } \mathrm{O}_{2} \\
\left(\mathrm{ml} \mathrm{kg}^{-1}\right)\end{array}$ & $\begin{array}{c}\mathrm{Total} \mathrm{O}_{2} \\
\left(\mathrm{ml} \mathrm{kg}^{-1}\right)\end{array}$ & $\begin{array}{c}\text { Respiratory } \\
(\%)\end{array}$ & $\begin{array}{c}\text { Blood } \\
(\%)\end{array}$ & $\begin{array}{c}\text { Muscle } \\
(\%)\end{array}$ \\
\hline 69 & 15 & 10.4 & 56 & 18 & 38 & 44 \\
125 & 15 & 19.8 & 65 & 30 & 32 & 38 \\
69 & 19 & 13.1 & 59 & 22 & 36 & 42 \\
125 & 19 & 23.8 & 69 & 34 & 31 & 35 \\
\hline
\end{tabular}




\section{Magnitude of $\mathrm{O}_{2}$ stores}

These $\mathrm{P}_{\mathrm{O} 2}$ data also indicate that $\mathrm{O}_{2}$ stores in the emperor penguin are greater than previously estimated. The air sac $\mathrm{P}_{\mathrm{O} 2}$ data yielded start-of-dive $\mathrm{O}_{2}$ fractions near $20 \%$, and, at times, end-of-dive $\mathrm{O}_{2}$ fractions that are near zero (Stockard et al. 2005). Assuming these data are representative of the entire respiratory system, this indicates that nearly complete depletion of the respiratory $\mathrm{O}_{2}$ store can occur in emperor penguins (i.e. the respiratory $\mathrm{O}_{2}$ fraction can decrease from $20 \%$ to $\pm 1 \%$, or respiratory $\mathrm{O}_{2}$ fraction $\Delta=19 \%$ ). This would increase the magnitude of the respiratory $\mathrm{O}_{2}$ store and change the distribution of $\mathrm{O}_{2}$ stores because most past calculations have assumed a respiratory $\mathrm{O}_{2}$ fraction $\Delta$ of $\leq 15 \%$ (Kooyman 1989, Croll et al. 1992, Kooyman \& Ponganis 1998). As calculated in Table 3, this increased extraction of $\mathrm{O}_{2}$ from the respiratory system would increase the total $\mathrm{O}_{2}$ store of emperor penguins by 3 to $4 \mathrm{ml} \mathrm{O} \mathrm{kg}^{-1}$. It has been hypothesized that a shift in the $\mathrm{O}_{2}$ affinity of emperor penguin $\mathrm{Hb}$, similar to that documented in other penguin species, at least partially accounts for the greater extraction of respiratory $\mathrm{O}_{2}$ in emperor penguins (Milsom et al. 1973, Ponganis et al. 2007). That shift in the $\mathrm{O}_{2}$ affinity of emperor penguin $\mathrm{Hb}$ has now been confirmed with a $\mathrm{P}_{50}\left(\mathrm{P}_{\mathrm{O} 2}\right.$ at $50 \% \mathrm{Hb}$ saturation) of $28 \mathrm{~mm} \mathrm{Hg}$ (Meir \& Ponganis 2009).

The venous $\mathrm{P}_{\mathrm{O} 2}$ data also indicate that blood $\mathrm{O}_{2}$ extraction can be greater than previously assumed (Ponganis et al. 2007, Ponganis et al. 2009). In Fig. 2, the initial venous $\mathrm{P}_{\mathrm{O} 2}$ of this 23.1 min dive is not only greater than that of a bird at rest (the value usually assumed in $\mathrm{O}_{2}$ store calculations), but nearly equivalent to arterial values of birds at rest (i.e. fully saturated $\mathrm{Hb})$. The final $\mathrm{P}_{\mathrm{O} 2}$ was $6 \mathrm{~mm} \mathrm{Hg}(0.8 \mathrm{kPa})$. This will result in an increase in the estimated available $\mathrm{O}_{2}$ stores (Table 3) and in the magnitude of an $\mathrm{ADL}_{\mathrm{C}}$. Given that almost complete depletion of fullysaturated $\mathrm{Hb}$ in the venous system can occur, total available $\mathrm{O}_{2}$ stores for a shallow $(<50 \mathrm{~m})$ dive would increase to $59 \mathrm{ml} \mathrm{O} \mathrm{Kg}^{-1}$ (22\% respiratory, $36 \%$ blood, $42 \%$ muscle), and for a deep (>100 m) dive (with a diving air volume of $125 \mathrm{ml}$ air kg${ }^{-1}$; Sato et al. 2002) to $69 \mathrm{ml} \mathrm{O}_{2} \mathrm{~kg}^{-1}$ (34\% respiratory, $31 \%$ blood, $35 \%$ muscle) (see Table 3). Because of increased air volume during deep dives and greater respiratory/ blood $\mathrm{O}_{2}$ extraction, the distribution of $\mathrm{O}_{2}$ stores during deep dives is almost equalized among the 3 compartments. Such a shift in $\mathrm{O}_{2}$ store distribution raises the question as to whether physiological responses and $\mathrm{O}_{2}$ store management might differ between deep and shallow dives in emperor penguins diving at sea.

\section{IMPLICATIONS FOR ADL}

\author{
$\mathrm{ADL}_{\mathrm{C}}$ definition
}

As emphasized in recent reviews (Butler 2004, 2006), the term, aerobic dive limit, has come to have 2 different definitions: (1) the dive duration associated with the onset of post-dive blood lactate accumulation and (2) the time 'required for all usable $\mathrm{O}_{2}$ stores to be consumed.' When the ADL was originally defined in Weddell seals as the dive duration associated with the onset of post-dive blood lactate elevation, it was also found that that ADL could be predicted by a calculation $\left(\mathrm{ADL}_{\mathrm{C}}=\mathrm{O}_{2}\right.$ stores $\div$ diving metabolic rate), in which the diving metabolic rate was the average $\mathrm{O}_{2}$ consumption measured over both the dive and surface intervals (Kooyman et al. 1980, Kooyman et al. 1983). It has been previously emphasized that this formula was originally used to simply predict the onset of post-dive lactate accumulation and not to describe the physiological mechanisms underlying that limit (Ponganis et al. 1997c,d, Kooyman \& Ponganis 1998). However, as pointed out in recent reviews, many researchers have used the formula to estimate the time required for total $\mathrm{O}_{2}$ store depletion (Butler 2004, 2006). This has led to 2 definitions of the ADL calculated by the same formula, and to the suggestion by Butler \& Jones (1997) that the dive duration associated with the onset of postdive lactate accumulation be called the diving lactate threshold (DLT). They suggest that the term ADL be defined as the time required for all usable $\mathrm{O}_{2}$ stores to be consumed.

\section{Findings}

This review of the diving physiology of the emperor penguin at the isolated dive hole demonstrates that $\mathrm{O}_{2}$ stores are not depleted at the ADL (onset of post-dive blood lactate accumulation, or DLT). These physiological findings also suggest that muscle is isolated from the blood and respiratory $\mathrm{O}_{2}$ stores during dives, and that muscle is the most likely site of lactate accumulation associated with the ADL. In order to predict the onset of post-dive lactate accumulation with the $\mathrm{O}_{2}$ store $/ \mathrm{O}_{2}$ consumption formula for emperor penguins with a body $\mathrm{O}_{2}$ store of $56 \mathrm{ml} \mathrm{O}_{2} \mathrm{~kg}^{-1}$ during these shallow dives, an $\mathrm{O}_{2}$ consumption rate of $2 \times$ the predicted rate of a $25 \mathrm{~kg}$ bird at rest (Aschoff \& Pohl 1970) would have to be used. Of note, the average diving metabolic rate in Weddell seals, which has been used to accurately predict the onset of post-dive lactate accumulation in that species, is also near $2 \times$ the predicted basal metabolic rate (Castellini et al. 1992, Ponganis et al. 1993). It must be emphasized again, that the formula, 
when used in this way, does not describe the physiological processes underlying the onset of post-dive lactate accumulation.

The blood $\mathrm{O}_{2}$ depletion data in Fig. 2 also provide the opportunity to use the formula to calculate the 'diving metabolic rate' required for all usable $\mathrm{O}_{2}$ stores to be consumed. Given the long 23.1 min duration of this dive and the near-zero final $\mathrm{P}_{\mathrm{O} 2}$, almost all available $\mathrm{O}_{2}$ stores were probably exhausted during this dive. If one were to calculate $23.1 \mathrm{~min}$ as the $\mathrm{ADL}_{\mathrm{C}}$, the diving $\mathrm{O}_{2}$ consumption rate used in the formula would be near $2.5 \mathrm{ml} \mathrm{O}_{2} \mathrm{~kg}^{-1} \mathrm{~min}^{-1}$, less than one-half the predicted resting metabolic rate of a $25 \mathrm{~kg}$ penguin (Aschoff \& Pohl 1970).

However, there are several issues in using the $\mathrm{ADL}_{\mathrm{C}}$ formula in this manner to calculate body $\mathrm{O}_{2}$ depletion and interpret diving/foraging behavior. First, the $\mathrm{O}_{2}$ consumption rate (one-half the basal rate) in the formula is not the actual diving metabolic rate; it is just the overall $\mathrm{O}_{2}$ store depletion rate. The actual diving metabolic rate is greater and consists of the $\mathrm{O}_{2}$ store depletion rate, the rate of glycolysis (lactate accumulation), and the rate of creatine phosphate breakdown. Therefore, the use of this formula to calculate the time required for depletion of all usable $\mathrm{O}_{2}$ stores is still a physiological black box just as was its original use to estimate the dive duration associated with post-dive blood lactate accumulation. Second, the common use of some form of a field metabolic rate to infer the diving metabolic rate to be used in a formula to calculate depletion of usable $\mathrm{O}_{2}$ stores is problematic (Butler 2004 , 2006). As demonstrated for the $23.1 \mathrm{~min}$ dive of the emperor penguin, if that field metabolic rate is greater than the rate at rest, its use in such an $\mathrm{ADL}_{\mathrm{C}}$ calculation will most likely underestimate the maximum available time for complete depletion of the usable $\mathrm{O}_{2}$ store. Third, the rarity of so long a dive in emperor penguins both at the isolated dive hole and in the wild questions the significance of such an $\mathrm{ADL}_{\mathrm{C}}$ in the interpretation of diving/foraging behavior. In a study of more than 137000 dives by 93 emperor penguins, only 2 dives were greater than 20 min and both were less than 23 min (Wienecke et al. 2007).

\section{CONCLUSIONS}

In emperor penguins diving at an isolated dive hole in McMurdo Sound, $\mathrm{O}_{2}$ store depletion rates appear to be regulated primarily by $\mathrm{HR}$ and by swimming efficiency. It is hypothesized that the diving bradycardia preserves the respiratory and blood $\mathrm{O}_{2}$ stores by decreasing tissue perfusion / $\mathrm{O}_{2}$ uptake, and by isolating muscle from the circulation. The depletion rate of the large $\mathrm{Mb}$-bound $\mathrm{O}_{2}$ store in muscle is con- served due to the efficiency of swimming. Extreme dive durations are dependent on hypoxemic tolerance. Although regional hypothermia may decrease thermoregulatory requirements for energy production during dives at the isolated dive hole, core hypothermia does not occur. Consequently, a significant hypothermic reduction in the metabolic rate is unlikely in central organs.

$\mathrm{P}_{\mathrm{O} 2}$ electrode data indicate that available $\mathrm{O}_{2}$ stores in the emperor penguin are greater than previously estimated due to the potential for (1) near-complete depletion of the respiratory $\mathrm{O}_{2}$ store and (2) start-ofdive venous $\mathrm{Hb}$ saturations near $100 \%$. In addition, previous studies have indicated that diving air volume is greater during deep ( $>100 \mathrm{~m}$ ) dives than shallow $(<50 \mathrm{~m})$ dives (Sato et al. 2002). These findings increase the total $\mathrm{O}_{2}$ store of the emperor penguin from $53 \mathrm{ml} \mathrm{O} \mathrm{kg}^{-1}$ to $59 \mathrm{ml} \mathrm{O}_{2} \mathrm{~kg}^{-1}$ during shallow $(<50 \mathrm{~m})$ dives and to $69 \mathrm{ml} \mathrm{O}_{2} \mathrm{~kg}^{-1}$ during deep (> $100 \mathrm{~m}$ ) dives.

The ADL, determined by the onset of post-dive blood lactate accumulation in emperor penguins at the isolated dive hole, is $5.6 \mathrm{~min}$. As evidenced by $\mathrm{P}_{\mathrm{O} 2}$ electrode data, blood and respiratory $\mathrm{O}_{2}$ stores are not depleted at the ADL. Active muscle is the most likely source of lactate accumulation at the ADL. Because $\mathrm{O}_{2}$ store depletion rates and physiological responses are variable, the ADL probably varies dependent on the nature and conditions of a given dive.

The $5.6 \mathrm{~min}$ ADL for shallow dives at the isolated dive hole can be predicted by an $\mathrm{O}_{2}$ store $/ \mathrm{O}_{2}$ consumption formula, in which $\mathrm{O}_{2}$ consumption is $2 \times$ the predicted metabolic rate of an emperor penguin at rest. When used in this way, the $\mathrm{ADL}_{\mathrm{C}}$ formula is a physiological black box in that it does not describe the physiological processes resulting in lactate accumulation.

The $\mathrm{ADL}_{\mathrm{C}}$ has also been defined as the time required for the consumption of all usable $\mathrm{O}_{2}$ stores. It is assumed that nearly complete exhaustion of all $\mathrm{O}_{2}$ stores occurred in an emperor penguin during a $23.1 \mathrm{~min}$ dive in which final venous $\mathrm{P}_{\mathrm{O} 2}$ was $6 \mathrm{~mm} \mathrm{Hg}$ $(0.8 \mathrm{kPa})$. Prediction of a $23.1 \mathrm{~min} \mathrm{ADL}_{\mathrm{C}}$ with the classic formula would require a diving $\mathrm{O}_{2}$ consumption value of about $0.5 \times$ the predicted rate at rest.

The ADL of emperor penguins at sea may be different from that of penguins at the isolated dive hole. This is due to differences between the magnitude and distribution of $\mathrm{O}_{2}$ stores between deep and shallow dives as well as to potential behavioral and physiological differences between dives at sea and those at the isolated dive. Based on the findings and techniques developed at the isolated dive hole, it is now time to investigate physiological responses and the ADL of emperor penguins at sea. 
Acknowledgements. We are grateful for the support of NSF grants 98144794, 0229638, and 0538594.

\section{LITERATURE CITED}

Aschoff S, Pohl H (1970) Rhythmic variation in energy metabolism. Fed Proc, Fed Am Soc. Exp Biol 29:1541-1552

Bevan RM, Woakes AJ, Butler PJ, Croxall JP (1995) Heart rate and oxygen consumption of exercising gentoo penguins. Physiol Zool 68:855-877

- Bevan RM, Boyd IL, Butler PJ, Reid KR, Woakes AJ, Croxall JP (1997) Heart rates and abdominal temperatures of freeranging South Georgian shags, Phalacrocorax georgianus. J Exp Biol 200:661-675

> Bevan RM, Butler PJ, Woakes AJ, Boyd IL (2002) The energetics of gentoo penguins, Pygoscelis papua, during the breeding season. Funct Ecol 16:175-190

Blix AS, Elsner RW, Kjekhus JK (1983) Cardiac output and its distribution through capillaries and A-V shunts in diving seals. Acta Physiol Scand 118:109-116

Boyd IL, Croxall JP (1996) Dive durations in pinnipeds and seabirds. Can J Zool 74:1696-1705

Butler PJ (2001) Diving beyond the limits. News Physiol Sci 16:222-227

Butler PJ (2004) Metabolic regulation in diving birds and mammals. Respir Physiol Neurobiol 141:297-315

Butler PJ (2006) Aerobic dive limit: What is it and is it always used properly? Comp Biochem Physiol A 145:1-6

Butler PJ, Jones DR (1997) The physiology of diving of birds and mammals. Physiol Rev 77:837-899

> Castellini MA, Costa DP, Huntley A (1986) Hematocrit variation during sleep apnea in elephant seal pups. Am J Physiol 251:R429-R431

Castellini MA, Kooyman GL, Ponganis PJ (1992) Metabolic rates of freely diving Weddell seals: correlations with oxygen stores, swim velocity, and diving duration. J Exp Biol 165:181-194

Chappell MA, Shoemaker VA, Jones DN, Maloney SK (1993) Diving behavior during foraging in breeding Adelie penguins. Ecology 74:1204-1215

Croll DA, Gaston AJ, Burger AE, Konnoff D (1992) Foraging behavior and physiological adaptation for diving in thickbilled murres. Ecology 73:344-356

Culik BM, Wilson RP, Bannasch R (1994) Under-water swimming at low energetic cost by Pygoscelid penguins. J Exp Biol 197:65-78

> Culik BM, Putz K, Wilson RP, Allers D, Lage J, Bost CA, Le Maho Y (1996) Diving energetics in king penguins (Aptenodytes patagonicus). J Exp Biol 199:973-983

Davis RW, Kanatous SB (1999) Convective oxygen transport and tissue oxygen consumption in Weddell seals during aerobic dives. J Exp Biol 202:1091-1113

Duran WN, Renkin EM (1974) Oxygen consumption and blood flow in resting mammalian skeletal muscle. Am J Physiol 226:173-177

Folkow B, Nilsson NJ, Yonce LR (1967) Effects of 'diving' on cardiac output in ducks. Acta Physiol Scand 70:347-361

Froget G, Butler PJ, Woakes AJ, Fahlman A, Kuntz G, Le Maho Y, Handrich Y (2004) Heart rate and energetics of free-ranging king penguins (Aptenodytes patagonicus). J Exp Biol 207:3917-3926

Gentry RL, Kooyman GL (eds) (1986) Fur seals: maternal strategies on land and at sea. Princeton University Press, Princeton, NJ

> Green JA, Butler PJ, Woakes AJ, Boyd IL (2003) Energetics of diving in macaroni penguins. J Exp Biol 206:43-57
Grubb BR (1981) Blood flow and oxygen consumption in avian skeletal muscle during hypoxia. J Appl Physiol 50: 450-455

> Handrich Y, Bevan RM, Charrassin JB, Butler PJ and others (1997) Hypothermia in foraging king penguins. Nature 388:64-67

Kooyman GL (1989) Diverse divers physiology and behavior, Vol 23. Springer-Verlag, Berlin

Kooyman GL, Kooyman TG (1995) Diving behavior of emperor penguins nurturing chicks at Coulman Island, Antarctica. Condor 97:536-549

Kooyman GL, Ponganis PJ (1998) The physiological basis of diving to depth: birds and mammals. Annu Rev Physiol 60:19-32

Kooyman GL, Wahrenbrock EA, Castellini MA, Davis RW, Sinnett EE (1980) Aerobic and anaerobic metabolism during voluntary diving in Weddell seals: evidence of preferred pathways from blood chemistry and behavior. J Comp Physiol 138:335-346

Kooyman GL, Castellini MA, Davis RW, Maue RA (1983) Aerobic dive limits in immature Weddell seals. J Comp Physiol 151:171-174

- Kooyman GL, Cherel Y, Le Maho Y, Croxall JP, Thorson PH, Ridoux V, Kooyman CA (1992a) Diving behavior and energetics during foraging cycles in king penguins. Ecol Monogr 62:143-163

> Kooyman GL, Ponganis PJ, Castellini MA, Ponganis EP and others (1992b) Heart rates and swim speeds of emperor penguins diving under sea ice. J Exp Biol 165:161-180

Meir JU, Ponganis PJ (2009) High-affinity hemoglobin and blood oxygen saturation in diving emperor penguins. J Exp Biol 212:3330-3338

- Meir JU, Stockard TK, Williams CL, Ponganis KV, Ponganis PJ (2008) Heart rate regulation and extreme bradycardia in diving emperor penguins. J Exp Biol 211:1169-1179

> Milsom WK, Johansen K, Millard RW (1973) Blood respiratory properties in some Antarctic birds. Condor 75:472-474

> Nagy KA, Kooyman GL, Ponganis PJ (2001) Energetic cost of foraging in free-diving emperor penguins. Physiol Biochem Zool 74:541-547

Niizuma Y, Gabrielsen GW, Sato K, Watanuki Y, Naito Y (2007) Brunnich's guillemots (Uria lomvia) maintain high temperature in the body core during dives. Comp Biochem Physiol A 147:438-444

> Ponganis PJ (2007) Bio-logging of physiological parameters in higher marine vertebrates. Deep Sea Res II 54:183-192

Ponganis PJ, Kooyman GL, Castellini MA (1993) Determinants of the aerobic dive limit of Weddell seals: analysis of diving metabolic rates, post-dive end tidal $\mathrm{P}_{\mathrm{O} 2}$ 's, and blood and muscle oxygen stores. Physiol Zool 66:732-749

Ponganis PJ, Costello ML, Starke LN, Mathieu-Costello O, Kooyman GL (1997a) Structural and biochemical characteristics of locomotory muscles of emperor penguins, Aptenodytes forsteri. Respir Physiol 109:73-80

> Ponganis PJ, Kooyman GL, Starke LN, Kooyman CA, Kooyman TG (1997b) Post-dive blood lactate concentrations in emperor penguins, Aptenodytes forsteri. J Exp Biol 200: 1623-1626

Ponganis PJ, Kooyman GL, Baronov EA, Thorson PH, Stewart BS $(1997 \mathrm{c})$ The aerobic submersion limit of Baikal seals, Phoca sibirica. Can J Zool 75:1323-1327

> Ponganis PJ, Kooyman GL, Winter LM, Starke LN (1997d) Heart rate and plasma lactate responses during submerged swimming and diving in California sea lions (Zalophus californianus). J Comp Physiol B 167:9-16

Ponganis PJ, Kooyman GL, Van Dam R, Le Maho Y (1999) Physiological responses of king penguins during simu- 
lated diving to $136 \mathrm{~m}$ depth. J Exp Biol 202:2819-2822

Ponganis PJ, Van Dam RP, Marshall G, Knower T, Levenson DH (2000) Sub-ice foraging behavior of emperor penguins. J Exp Biol 203:3275-3278

Ponganis PJ, Van Dam RP, Knower T, Levenson DH (2001) Temperature regulation in emperor penguins foraging under sea ice. Comp Biochem Physiol A 129:811-820

Ponganis PJ, Van Dam RP, Levenson DH, Knower T, Ponganis KV, Marshall G (2003) Regional heterothermy and conservation of core temperature in emperor penguins diving under sea ice. Comp Biochem Physiol A 135:477-487

Ponganis PJ, van Dam RP, Knower T, Levenson DH, Ponganis KV (2004) Deep dives and aortic temperatures of emperor penguins: new directions for bio-logging at the isolated dive hole. Mem Natl Inst Polar Res 58(Special Issue): 155-161

Ponganis PJ, Stockard TK, Meir JU, Williams CL, Ponganis KV, van Dam RP, Howard R (2007) Returning on empty: extreme blood $\mathrm{O}_{2}$ depletion underlies dive capacity of emperor penguins. J Exp Biol 210:4279-4285

Ponganis PJ, Kreutzer U, Stockard TK, Lin PC and others (2008) Blood flow and metabolic regulation in seal muscle during apnea. J Exp Biol 211:3323-3332

Ponganis PJ, Stockard TK, Meir JU, Williams CL, Ponganis $\mathrm{KV}$, Howard $\mathrm{R}$ (2009) $\mathrm{O}_{2}$ store management in diving emperor penguins. J Exp Biol 212:217-224

Sato K, Naito Y, Kato A, Niizuma Y and others (2002) Buoyancy and maximal diving depth in penguins: Do they control inhaling air volume? J Exp Biol 205:1189-1197

Scholander PF (1940) Experimental investigations on the respiratory function in diving mammals and birds. Hvalrad Skr 22:1-131

Shiomi K, Sato K, Mitamura H, Arai N, Naito Y, Ponganis PJ (2008) Effect of ocean current on the dead-reckoning estimation of 3D dive paths of emperor penguins. Aquat Biol

Submitted: August 5, 2009; Accepted: December 1, 2009
3:265-270

Stockard TK, Heil J, Meir JU, Sato K, Ponganis KV, Ponganis $\mathrm{PJ}$ (2005) Air sac $\mathrm{P}_{\mathrm{O} 2}$ and oxygen depletion during dives of emperor penguins. J Exp Biol 208:2973-2981

Stockard TK, Levenson DH, Berg L, Fransioli JR, Baranov EA, Ponganis PJ (2007) Blood oxygen depletion during restassociated apneas of northern elephant seals (Mirounga angustirostris). J Exp Biol 210:2607-2617

Valtin H (1973) Renal function: mechanisms preserving fluid and solute balance in health. Little, Brown \& Co, Boston, MA

van Dam RP, Ponganis PJ, Ponganis KV, Levenson DH, Marshall G (2002) Stroke frequencies of emperor penguins diving under sea ice. J Exp Biol 205:3769-3774

Watanuki Y, Kato A, Mori Y, Naito Y (1993) Diving performance of adelie penguins in relation to food availability in fast sea-ice areas: comparison between years. J Anim Ecol 62:634-646

Wienecke B, Robertson G, Kirkwood R, Lawton K (2007) Extreme dives by free-ranging emperor penguins. Polar Biol 30:133-142

Williams TM (2001) Intermittent swimming by mammals: a strategy for increasing energetic efficiency during diving. Am Zool 41:166-176

Williams TM, Davis RW, Fuiman LA, Francis J and others (2000) Sink or swim: strategies for cost-efficient diving by marine mammals. Science 288:133-136

Williams TM, Fuiman LA, Horning M, Davis RW (2004) The cost of foraging by a marine predator, the Weddell seal Leptonychotes weddellii: pricing by the stroke. J Exp Biol 207:973-982

> Zapol WM, Liggins GC, Schneider RC, Qvist J, Snider MT, Creasy RK, Hochachka PW (1979) Regional blood flow during simulated diving in the conscious Weddell seal. J Appl Physiol 47:968-973

Proofs received from author(s): March 10, 2010 